\title{
A Polite Foucault? : Eighteenth-Century Politeness as a Disciplinary System and Practice of the Self
}

\section{Ylivuori, Soile}

2014

Ylivuori , S 2014 , ' A Polite Foucault? Eighteenth-Century Politeness as a Disciplinary

System and Practice of the Self ' , Cultural History , vol. Volume 3 , no. 2 , pp. 170-189 . https://doi.org/10.3366/cult.

http://hdl.handle.net/10138/136445

https://doi.org/10.3366/cult.2014.0069

acceptedVersion

Downloaded from Helda, University of Helsinki institutional repository.

This is an electronic reprint of the original article.

This reprint may differ from the original in pagination and typographic detail.

Please cite the original version. 
Cultural History 3.2 (2014): 170-189

DOI: $10.3366 /$ cult.2014.0069

(C) Edinburgh University Press

www.euppublishing.com/cult

\title{
A Polite Foucault? \\ Eighteenth-Century Politeness as \\ a Disciplinary System and Practice of the Self
}

\author{
SOILE YLIVUORI \\ University of Helsinki
}

\begin{abstract}
Eighteenth-century politeness as a means of creating identity has recently been under much scholarly investigation but has not been properly considered in the light of theoretical approaches to identity and subjectivity. This article examines politeness within two Foucauldian theoretical frameworks: as a disciplinary system and as an enabling practice of the self. The first approach sheds light on politeness as a kind of panopticon - an apparatus of power/knowledge that produces normative identity through constant surveillance. The second approach examines politeness from the individual's perspective, mapping out strategies of assuming and building polite subjectivity. My argument is that eighteenthcentury politeness was not only a normalizing system of power, but also a practice of individuality and freedom. On this basis, I claim that a Foucauldian theoretical approach provides a fruitful new reading of politeness, opening up new areas of research.
\end{abstract}

\section{Introduction}

During the past few decades, seventeenth- and eighteenth-century politeness - a set of discourses and practices constructing elite identity - has become a fairly popular area of historical study. ${ }^{1}$ Scholars have focused especially on politeness and its ties to political thought and commercialism, as well as its links to earlier forms of civility and courtesy. Besides these, politeness has been linked to gender studies: researchers have written extensively on the construction of masculinity through politeness, and on

\footnotetext{
${ }^{1}$ I would like to thank Anu Korhonen and Markku Kekäläinen for their valuable comments on drafts of this article, as well as J. F. van Dijkhuizen for his meticulous proofreading. The research for this article was enabled by the funding of the Finnish Cultural Foundation.
} 
masculine politeness in general. For example, Philip Carter (2001) and Michèle Cohen (1996) have concluded that politeness had a major impact on different views of masculinities. ${ }^{2}$ Since gender and politeness has been an area of academic interest, it is surprising that studies about feminine politeness are relatively few. ${ }^{3}$ Even though it seems apparent that politeness had just as much impact on feminine norms and ideals as on masculine ones, there are no extensive studies mapping the connections between politeness and construction of femininity. Further, while politeness has been studied from a gender perspective, historians have not taken genuine advantage of the methodologies of gender studies. Instead, their methods have generally been traditionally historical, and such issues as the discursive nature of identity or the performativity of gendered politeness have remained unexamined. The main influence behind these topics - discussed extensively by such prominent gender studies scholars as Judith Butler - is Michel Foucault's body of work and especially his analyses of power, knowledge and subjectivity. ${ }^{4}$

In this article, I will provide a novel reading of eighteenth-century discourses of female politeness by examining them from a Foucauldian perspective. My analysis deals with politeness in two separate Foucauldian aspects: as a technology of power and as a technology of the self. This approach gives a twofold view on politeness from both the discursive and the individual angle. In the first part of the paper, based on Foucault's notion of the panopticon in Discipline and Punish, I will discuss politeness as a disciplinary power producing docile bodies. The second part leans heavily on Foucault's later writings, especially on The Use of Pleasure, volume 2 of History of Sexuality. I will examine polite identities from the individual's point of view as enabling practices, paradoxically, of both freedom and self-control. The first section draws on a variety of polite literature, such as conduct books, novels, sermons, and periodicals. The second part employs Fanny Burney's early journals as a case study, complementing them with some additional material, such as Lawrence E. Klein's analysis of the notebooks of the Earl of Shaftesbury. My approach will not only examine politeness from a new perspective but will also

\footnotetext{
${ }^{2}$ Carter, Philip (2001), Men and the Emergence of Polite Society, Britain 1660-1800, Harlow: Longman; Cohen, Michèle (1996), Fashioning Masculinity: National Identity and Language on the Eighteenth Century, London: Routledge.

${ }^{3}$ On feminine politeness see e.g. Tague, Ingrid H. (2002), Women of Quality: Accepting and Contesting Ideals of Feminity in England, 1690-1760, Woodbridge: Boydell Press; Glover, Katharine (2011), Elite Women and Polite Society in Eighteenth-Century Scotland, Woodbridge: Boydell Press; Jones, Vivien (1990), Women in the Eighteenth Century: Constructions of Femininity, London: Routledge; Vickery, Amanda (1998), The Gentleman's Daughter: Women's Lives in Georgian England, New Haven: Yale University Press; Armstrong, Nancy (1987), Desire and Domestic Fiction: A Political History of the Novel, Oxford: Oxford University Press. None of these, however, deal extensively with politeness as a gendered ideology; instead, politeness is given a fairly cursory and simplistic treatment. Jenny Davidson (2004) is a refreshing exception to this rule; her book Hypocrisy and the Politics of Politeness: Manners and Morals from Locke to Austen (Cambridge: Cambridge University Press) gives a detailed account of hypocrisy as a feminine tactic of negotiating social pressure with individual aspirations.

${ }^{4}$ Butler, Judith (1990), Gender Trouble: Feminism and the Subversion of Identity, New York: Routledge.
} 
contribute to the feminist body of work that uses Foucault's theories to analyse power structures of everyday life, especially when related to gender. ${ }^{5}$

I work from the assumption that politeness was a set of sociable practices used as a means of building identity, and also that politeness was a highly gender-specific set of codes with an important bodily dimension. Yet while politeness was a discursive formation that produced normative gendered bodies, this point of view is too narrow, since it does not address the formation of subjectivity. The power/knowledge model of Foucault's earlier writings is highly useful analysis of polite discourse, yet it also seems somewhat mechanistic and insufficient to account for the willing acceptance of the polite subject position(s). Foucault's earlier work was based largely on building different genealogies and exposing the large-scale epistemes through which subjectivity is constructed; only in the 1980s did he turn his focus to the subjects themselves. Foucault acknowledges this himself, writing in the introduction to The Use of Pleasure that he has in his previous works neglected the proper analysis of subjectivity. He states that in order to analyse 'the subject', one has to look for 'the forms and modalities of the relation to self by which the individual constitutes and recognizes himself qua subject. $^{6}$ Thus, in The Use of Pleasure Foucault provides an intricate analysis of the ways in which power/knowledge is managed on an individual level, and negotiated into subjectivity through different techniques of the self. Besides this, as for instance Johanna Oksala has claimed, the book can also be seen as a guide to individual techniques of resistance and freedom. ${ }^{7}$

\section{Politeness as a Technology of Power}

Michel Foucault describes the properties of discipline in Discipline and Punish as follows: '[D]iscipline fixes; it arrests or regulates movements; it clears up confusion; it dissipates compact groupings of individuals wandering about the country in unpredictable ways. ${ }^{8}$ The same description could also be applied to eighteenth-century politeness. The aim of politeness, too, was to regulate movements (both of people and of their limbs), to prevent confusion among the polite, and to eliminate all kinds of unpredictability within the social sphere. Indeed, politeness was very much a disciplinary system as Foucault describes it. In the first part of this paper, I will examine the disciplinary characteristics of politeness in some detail; I will show that polite discourse was a practice of gendered power, but that the power was by no means easily visible or straightforwardly repressive.

\footnotetext{
${ }^{5} \mathrm{My}$ theoretical debt on this issue is especially to Judith Butler, Cressida Heyes, Susan Bordo, Johanna Oksala and Elizabeth Grosz.

${ }^{6}$ Foucault, Michel (1992), The Use of Pleasure: The History of Sexuality, Vol. 2, transl. Robert Hurley, London: Penguin Books, p. 6.

${ }^{7}$ Oksala, Johanna (2005), Foucault On Freedom, Cambridge: Cambridge University Press, pp. 157-63.

${ }^{8}$ Foucault, Michel (1995), Discipline and Punish: The Birth of the Prison, transl. Alan Sheridan, New York: Vintage Books, p. 219.
} 


\section{Gendered Surveillance}

Politeness was a highly visual culture. ${ }^{9}$ Revealing itself in multiple ways of standing, walking, gesturing, dressing and facial expressions, politeness had a distinctly visual dimension - up to the point where polite society could evaluate a person's level of politeness merely by looking. A particularly accomplished woman caught the eye of Will Honeycomb, one of the characters in the famous moralist periodical The Spectator: 'How is the whole Woman expressed in her Appearance! Her Air has the Beauty of Motion, and her Look the Force of Language. ${ }^{10}$ Indeed, women especially were seen as having been born to be watched: 'To be admired, seems, indeed, the peculiar priviledge of your Sex,' wrote John Burton in his conduct book addressing women. ${ }^{11}$ Thus, the act of watching was a gendered event, in which women were the objects of gaze, and men the gazing subjects. This arrangement was usually legitimized by naturalizing it in different ways: for example, beauty, which was considered to be an innate feminine characteristic, was said to have a natural ability to captivate the eye. ${ }^{12}$

Elite women grew up knowing that polite society observed their every move, every lace on their gown and every nod of their head; they were also taught constantly to observe themselves in order to appear to their best advantage. For example, The Polite Academy instructed ladies to keep in mind that as they were constantly under surveillance, they should cultivate means of assuring the (male) gazer of their feminine graces: 'Women, who are sensible that they are the Objects of Love, and born to be admired, are ever changing the Air of their Faces, and the Attitude of their Bodies, to strike the Gazer's Heart with new Impressions of their Beauty. ${ }^{13}$

I argue that polite society closely resembled the panopticon that Foucault describes in Discipline and Punish. Like the panopticon, polite society was 'a state of conscious and permanent visibility that assures the automatic functioning of power'. ${ }^{14}$ Polite society was based on constant self-monitoring brought on by the state of constant visibility. As Foucault explains, this makes the supervising power invisible, automatized and deindividualized..$^{15}$ The awareness of constant supervision made polite individuals into their own supervisors. Like Bentham's original panopticon, moreover, the polite panopticon was a

\footnotetext{
${ }^{9}$ See e.g. Klein, Lawrence E. (1994), Shaftesbury and the Culture of Politeness: Moral Discourse and Cultural Politics in Early Eighteenth-Century England, Cambridge: Cambridge University Press, pp. 76-80.

10 The Spectator, No. 4, March 5, 1711.

${ }_{11}$ Burton, John (1793), Lectures on female education and manners, Vol. 1, Rochester: Gillman and Etherington, p. 197.

${ }^{12}$ See e.g. Korhonen, Anu (2009), 'To see and to be seen: beauty in the early modern London street', in Cultural History of Early Modern European Streets, ed. Riitta Laitinen and Thomas V. Cohen, Leiden: Brill, pp. 141-66. The objectification of women was by no means peculiar to eighteenth-century politeness. In this respect, polite identity as a performative series of appearances and deeds can be compared to any other identity.

13 The Polite Academy, or school of behaviour for young gentlemen and ladies (1762), London: R. Baldwin and B. Collins, pp. xi-xii.

${ }^{14}$ Foucault, Discipline and Punish, p. 201.

${ }^{15}$ Foucault, Discipline and Punish, p. 201.
} 
machine of training and correcting individuals. It was a self-monitoring, self-repairing and selfsufficient system for creating normality and imposing it efficiently on individuals - or, as Foucault puts it, it ws an apparatus or dispositif that used discursive power/knowledge to produce homogenous individuals. ${ }^{16}$ This power dynamic did not operate by means of violence - quite the opposite. As Judith Butler writes in Gender Trouble,

The strategy has not been to enforce a repression of their desires, but to compel their bodies to signify the prohibitive law as their very essence, style, and necessity. The law is not literally internalized, but incorporated, with the consequence that bodies are produced which signify that law on and through the body; the law is manifest as the essence of their selves, the meaning of their soul, their conscience, the law of their desire. In effect, the law is at once fully manifest and fully latent, for it never appears as external to the bodies it subjects and subjectivates. ${ }^{17}$

The polite panopticon was not overtly repressive but instead created desirability in a subtle manner, by recasting it as mode, elegance, good breeding and respectability. However, this did not lessen its repressive force, since the norms of desirability were by definition exclusionary. They were also heteronormative, as we shall see shortly. Polite power was subtle, but normative and compelling all the same.

In Foucault's idea of the panopticon as an exercise of power, there is always inevitably a hierarchy of power inscribed within the system. The polite discursive ideal, where women were born to be watched just as surely as men were born to be their watchers, reveals that the polite panopticon was based on masculine hegemony, feminine subordination and the juxtaposition of these two. Women's individuality was continuously defined in relation to men, to the extent that it was men's desires that dictated feminine ideality. ${ }^{18}$ In addition, femininity was constructed mainly in opposition to masculinity. Although it was also women who observed themselves and others, they were supposed to do so through masculine spectacles. Yet the circulation of power was by no means clear-cut, only bringing men power through the knowledge they accumulated from the observation of women. Instead, as Manushag Powell has demonstrated, men were also expected to behave as if women were watching them. ${ }^{19}$ Many scholars have pointed out that the women of polite society were seen as 'civilizing agents', forcing men to refine their behaviour, and therefore of vital importance to polite sociability. ${ }^{20}$ Masculine identity was, in the end, just as dependent on feminine identity as femininity was on

\footnotetext{
${ }^{16}$ Foucault, Discipline and Punish, pp. 199-207. Since the dispositif consists of many separate and intermingled layers of discourses and institutions, it unavoidably includes superficial incoherencies.

${ }^{17}$ Butler, Gender Trouble, p. 183. See also Foucault, Discipline and Punish, pp. 30-41.

${ }^{18}$ E.g. Fordyce, James (1766), Sermons to young women, $6^{\text {th }}$ ed., London: D. Payne, p. 126: 'Your business chiefly is to read Men, in order to make yourselves agreeable and useful.'

${ }_{19}$ Powell, Manushag N. (2012), 'See No Evil, Hear No Evil, Speak No Evil: Spectation and the Eighteenth-Century Public Sphere', in Eighteenth-Century Studies, Vol. 45 Nr. 2, p. 263.

${ }^{20}$ See e.g. Carter, Men and the Emergence; Cohen, Fashioning Masculinity.
} 
masculinity. As Powell puts it, 'men regulate the women who will regulate the men. ${ }^{, 21}$ However, even if women had some power of spectatorship, too, the fundamental power structure was always based on men's needs, men's refinement and men's desires.

\section{Bodily Performances}

The truth produced within polite discourse was, ambiguous, self-contradicting and incoherent. ${ }^{22}$ Indeed, according to Foucault, this is the case for all truth regimes. Within polite discourse, there were several competing views of politeness that were constantly being reformulated and contested. In spite of this, the majority of polite writers shared a a concern with the visibility of politeness. This was because, whatever the specifics of polite ideology, politeness had to be visible to the other members of the panopticon. As Judith Butler has pointed out, identity is a performative construction, and polite identity was no exception. ${ }^{23}$ In fact, politeness necessarily centered around visibility and performance. As, Markku Kekäläinen has observed, especially early eighteenth-century politeness had many theatrical elements: polite sociability was seen as a performative display of the art of pleasing, and polite identity was a theatrical act of self-fashioning. ${ }^{24}$ Even such vociferous opponents of theatrical politeness as Joseph Addison or the Third Earl of Shaftesbury, who thought that politeness was the natural outcome of inner virtue and antithetical to all enactment, agreed that it still needed to be knowingly portrayed to the world. ${ }^{25}$ Even for people who censored theatrical display, politeness was a performative act.

It has often been noted that performative identity is acted out through various bodily acts. ${ }^{26}$ Although Foucauldian poststructuralist theorists such as Judith Butler define the body primarily as a cultural construct, Foucault's own conception of the body has been the subject of some debate. He clearly sees the body as discursively constructed, but it has been somewhat unclear how strongly this should be interpreted. ${ }^{27}$ Here I utilize the so-called strong version of interpretation, used by such scholars as Elizabeth Grosz or Susan Bordo, which focuses on the extent to which the body is a

\footnotetext{
${ }^{21}$ Powell, 'See No Evil', p. 271.

${ }^{22}$ Foucault, The Use of Pleasure, pp. 29-30.

${ }^{23}$ Butler, Gender Trouble, p. 185.

${ }^{24}$ Kekäläinen, Markku (2012), James Boswell's Urban Experience in Eighteenth-Century London, Helsinki: Unigrafia, pp. 4-8, $125-7$. PDF-file: http://urn.fi/URN:ISBN:978-925-10-7952-8

${ }^{25}$ Klein, Shaftesbury, p. 92.

${ }^{26}$ Butler, Gender Trouble, p. 185. See also e.g. Bordo, Susan (1997), 'The Body and the Reproduction of Femininity', in Writing on the Body: Female Embodiment and feminist theory, ed. Katie Conboy, Nadia Medina and Sarah Stanbury, New York: Columbia University Press, pp. 90-110.

27 Johanna Oksala distinguishes three possible interpretations of Focault's discursive body - the weak (linguistic understanding only, says nothing about the actual body), the intermediate (body has a stable core that can't be manipulated, even though cultural construction plays a part), and the strong (denies any dimensions of embodiment not culturally or historically constructed). (Oksala, Foucault On Freedom, pp. 117-9)
} 
cultural construction rather than an ahistorical or biological reality. ${ }^{28}$ The body is thereby seen as a surface on which the central rules, hierarchies, and commitments of a culture are inscribed and thus reinforced; it is a set of actions, routines and exercises that reflects discursive ideals imposed on it as performative deeds, postures, gestures, and appearances.

Accordingly, a polite woman had to be able to portray her feminine politeness through her body as clearly as possible. At the same time, this performance also constructed her identity as a polite woman for her and was therefore an act of creating a docile, normative polite body - this is what Foucault might have called the dipositif of polite disciplinary power in action. ${ }^{29}$ Elite women were under a polite

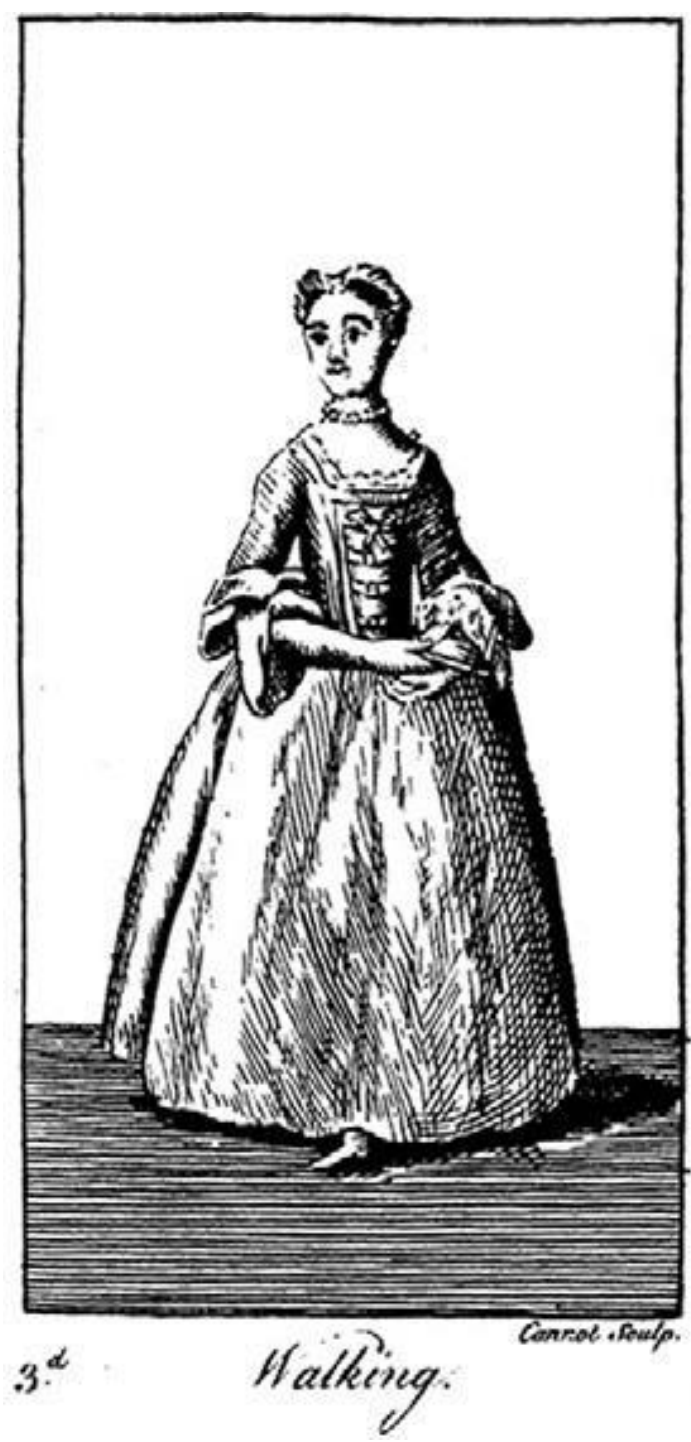

Figure 1: The correct way of 'Walking', from The Polite Academy (1762). truth regime that constantly pressured and advised them on feminine polite ideality. The discursive instructions were often highly specific and detailed, as is the case with the guide to correct walking by The Polite Academy, which not only gave step-by-step instructions but also presented the reader with an image of the correct posture:

1. Hold up your Head without any stiffness. 2. Keep your whole person upright. 3. Let your shoulders fall easily. 4. Drop your Arms easily and gracefully down to the waist. 5. Then place the Hands on one another, with the Palms turning upward, and a little inward. 6. Take short steps and do not lift up your Feet too high. 7. Let the Foot that was up, be brought down slowly, and with an easy Motion. 30

In order to become polite subjects, women were obliged to practice, not only walking, but also such other basic bodily skills such as curtsying, sitting and dancing. In addition, women were required to master many kinds of special accomplishments - such as singing, playing the piano, drawing and needlework - that were meant to be displayed in company and make women the objects of the polite supervising gaze. ${ }^{31}$ Even though opinions on the correct manner of performing varied, all writers agreed that ideal

\footnotetext{
${ }^{28}$ Grosz, Elizabeth (1994), Volatile Bodies: Toward a Corporeal Feminism, Bloomington: Indiana University Press, pp. 141-2; Bordo, 'The Body', p. 90.

${ }^{29}$ For the creation of individuals within a dispositif, see Foucault, Discipline and Punish, p. 217.

30 The Polite Academy, p. 49.

${ }^{31}$ E.g. Burton, Lectures, Vol. 1, p. 29. 'You are not only to be instructed in elegant accomplishments, but also be taught the useful arts, so that you may be capable of appearing to advantage, both at home and abroad.' See also Carter, Men and the Emergence, pp. 21-2.
} 
feminine politeness should be something opposite to, or at least different from, masculine ideality. To a large extent, politeness was a dichotomist system in which truth was organized on a gendered basis. In his famous sermon for women Reverend James Fordyce spoke of his horror at any transgression of gender roles, especially if the offender was a woman:

A masculine woman must be naturally an unamiable creature. [...] a young woman of any rank, that throws away all the lovely softness of her nature, and emulates the daring intrepid temper of a man - how terrible! [...] What though the dress be kept ever so distinct, if the behaviour is not; in those points, I mean, where the character peculiar to each sex seems to require a difference? There a metamorphosis in either will always offend an eye that is not greatly vitiated. It will do so particularly in your sex. [...] To the men an Amazon, I think, never fails to be forbidding. ${ }^{32}$

Femininity was usually equated with gracefulness, softness, modesty and sensibility - opposed to masculinity, which was supposed to be bold, forceful and rough. ${ }^{33}$ Thus, gendered ideality was built on a system of differentiation.

Besides these active performative practices, polite discourse also imposed a large spectrum of demands for bodily discipline on women. Women were told that they should control their different passions, such as anger, gluttony, self-indulgence, and most importantly, sexual desire. You will be under the impulse of affections, either judiciously regulated, or immoderately indulged,' wrote John Burton. $^{34}$ These demands for discipline arose from different epistemes - partly from civility and sociability, partly from the ideas of corporeality and anatomy at the time, and partly from Christian morality and domesticity. ${ }^{35}$ Like bodily practice, the rhetoric of bodily discipline was designed to (re)produce gender distinctions. John Gregory wrote in his guide that the luxury of eating is a despicable selfish vice in men, but in your sex it is beyond expression indelicate and disgusting. ${ }^{36}$ Especially chastity was represented as the ultimately feminine virtue, without which ' wit, beauty, sense, knowledge, and every other female accomplishment, are not only useless and insignificant, but frequently destructive and pernicious. ${ }^{37}$

\footnotetext{
32 Fordyce, Sermons, p. 53. See also e.g. The Spectator, No. 435, July 19, 1712, where Joseph Addison denounces female horseback riders as immodest 'hermaphrodites' and 'monsters'.

${ }^{33}$ E.g. Gregory, John (1788), A father's legacy to his daughters, $3^{\text {rd }}$ ed., Dublin: H. Chamberlaine, pp. 16-27; Wollstonecraft, Mary (1787), Thoughts on the education of daughters: with reflections on female conduct, in the more important duties of life, London, p. 31; Fordyce, Sermons, p. 71.

34 Burton, Lectures, Vol. 1, p. 71.

35 See e.g. More, Hannah (1799), Strictures on the Modern System of Female Education, Vol. 2, London: T. Cadell Jun. and W. Davies, pp. 191, 224-5; Fordyce, Sermons, 7-10.

${ }^{36}$ Gregory, Legacy, p. 24.

${ }^{37}$ Allen, Charles (1760), The Polite Lady: or, a Course of Female Education, London: J. Newbery, p. 193.
} 


\section{Paradoxes of Control}

If the virtues allotted to ideal femininity, such as graceful dancing or absolute chastity, did not come naturally to individuals, they had to be vigorously practiced through the discursive guidance provided by didactic literature. However, at the same time this same literature presented femininity as natural to all women. ${ }^{38}$ In this controversy, the twofold nature of polite discourse as both fixing and productive a structure can be clearly seen: polite discourse presented gender difference as a natural, eternal, ahistorical phenomenon while at the same time actively defining and constructing it. Therefore, it was necessary both to give women specific guidance about disciplining their bodies into polite normality while also assuring them that this normality was what they had possessed all along. In this way, the polite panopticon produced individuals who maintained and reproduced the gendered identities that were made desirable for them by implied promises of social acceptability.

Yet although the requirement of relentless control appears to have been the main goal of polite demands for women, it was not the ultimate goal. One must separate from each other the operating principles of the panopticon and the actual demands made on the feminine individual. Even though polite identity was indeed built through constant supervision, the demands for restraint were in fact highly ambiguous. In the midst of the demands for bodily control and even chastity, a voice can be traced reminding women that they would not be able to accomplish all this. Women were told again and again how they should not gossip, but at the same time it was implied that this behaviour came naturally to women. In ideal femininity, too much bodily control was just as big a faux pas as too little. Women were, in the end, seen as the more irrational and sentimental sex, and true womanhood involved the ability to melt into tears, to sigh and blush, to experience uncontrollable tremors and palpitations, and occasionally to faint. ${ }^{39}$ It was even debated whether women were capable of controlling their bodies at all. Restraining one's urges meant subjugating them to reason, and rationality was by definition a masculine virtue. In the eighteenth century, women were seen as less rational and more governed by their emotions than men, and because of this society was built on masculine domination and feminine subordination. Since women were not capable of rationality, total restraint and therefore civic responsibility could not be expected of them. ${ }^{40}$ Thus, extreme discipline in a woman made her a dubious character and her gender questionable.

\footnotetext{
${ }^{38}$ E.g. The Polite Academy, p. xxiv.

${ }^{39}$ E.g. Fordyce, Sermons, p. 87. See also Mullan, John (1988), Sentiment and Sociability: The Language of Feeling in the Eighteenth Century, Oxford: Clarendon Press, pp. 61, 74, 112-13.

${ }^{40}$ Foucault, The Use of Pleasure, 80-4. The eighteenth-century medical understanding of the female body also included the view women being governed by their uterus, causing uncontrollable sentimentality and hysteria. (Mullan, Sentiment, pp. 20727; see also Kaplan, Cora (1987), 'Wild nights: pleasure/sexuality/feminism', in The Ideology of Conduct: Essays on Literature and the History of Sexuality, ed. Nancy Armstrong and Leonard Tennenhouse, New York: Methuen, pp. 161-2.)
} 


\section{Politeness as a Technology of the Self}

As the previous section has demonstrated, politeness was very much a disciplinary technology of power that served to produce docile polite bodies. Yet we cannot form an adequate picture of polite society by analyse merely the practices of power, and by viewing women exclusively as the subjects of this power. Accordingly, in this section I examine the panopticon from the individual's point of view. Foucault writes in The Use of Pleasure that submitting to a code of conduct requires forming oneself as an ethical subject that acts in deference to the prescriptive elements which make up that code. ${ }^{41}$ This requires a specific kind of self-cultivation which Foucault sees as a form of 'ethical work' which 'one performs on oneself, not only in order to bring one's conduct into compliance with a given rule, but to attempt to transform oneself into the ethical subject of one's behaviour. ${ }^{42}$ This can be attained through specific care of the self (epimeleia heautou), which includes self-control (enkrateia), self-knowledge and careful training (askêsis). ${ }^{43}$ The goal of this self-care is to establish the required identity as an ethical choice and an aesthetic form of self-fashioning. Eighteenth-century polite women were not merely forced to act according to the rules of politeness, but they also actively worked on themselves in order to internalize the polite feminine identities and to become true polite subjects. Politeness could also provide freedom and enabling positions for women by offering them self-knowledge and social power, as well as feelings of self-learning and mastery.

\section{Shaftesbury and enkrateia}

Lawrence E. Klein touches on the subject of Foucauldian self-care within the context of politeness in his book Shaftesbury and the Culture of Politeness, in which he describes the troubles the Third Earl of Shaftesbury experienced when trying to overcome his doubts about and difficulties in becoming a polite subject. As Foucault writes, enkrateia is an active battle rather than a form of passive self-denial, and according to Klein's interpretation of Shaftesbury's notebooks, assuming a polite subjectivity was indeed a battle for Shaftesbury. Shaftesbury's problem was the conflict between the autonomous self and the sociable self: he was afraid that his desire to please others might steer him away from his true self. Shaftesbury was torn between the requirements of politeness on the one hand and the obligations to the self on the other. He often worried that self-love, 'the self's insatiable psychological hunger for the esteem and love of others,' would make him sacrifice his autonomy and turn himself into a mere

\footnotetext{
${ }^{41}$ Foucault, The Use of Pleasure, p. 26.

42 Ibid. p. 27.

43 Ibid. p. 73.
} 
display of politeness. ${ }^{44}$ As a solution, Shaftesbury proposed the enhancement of one's moral autonomy through the expansion of the self's interiority - or in other words, he saw his interior space as a sphere of control and aimed to filter, examine and appraise every outer influence through that sphere. The result of this process would be a truly internalized new kind of politeness - rational sociability - that would not be based on external impulses, but on the stable core of the rational self. ${ }^{45}$

In Foucauldian terms, what Shaftesbury proposed to embark on was a process of self-formation: through careful self-examination, self-knowledge and vigorous training he aimed to make himself an ethical polite subject, rather than acting on either external pressure or the uncontrolled passion of selflove. This was not to be done in deference to a disciplinary system forcing its ideals but in order to resolve the problem of the self - to live truthfully and to become a moral subject instead of a hypocritical actor. Yet the aim of this process was not self-discovery, but self-fashioning: Shaftesbury was all the time aware that he was 'replacing an untoward disposition with another more advantageous one. ${ }^{46}$ Also, Shaftesbury's goal was not to eradicate desire but to control it - exactly as Foucault describes the practice of enkrateia. Klein also points out that Shaftesbury read the Roman Stoics and was familiar with their practices of moral training. Accordingly, he kept notebooks that he actually called askèmata, 'exercises', in which he meticulously wrote down his thoughts on and doubts about politeness, subjectivity and the problem of becoming an autonomous individual. Klein sees these notebooks as part of the therapeutic process whose aimed was to advance moral transformation through self-reflection. ${ }^{47}$ We could also usefully see them as bypomnemata, 'notebooks' that Foucault variously describes as 'a material memory of things read, heard, or thought, thus offering these as an accumulated treasure for rereading and later meditation' and as 'raw material for the writing of more systematic treatises in which were given arguments and means by which to struggle against some defect'. This is in fact precisely how Shaftesbury used them. Hypomnemata were 'explicitly oriented to the care of oneself, toward definite objectives such as retiring into oneself, reaching oneself, living with oneself, being sufficient to oneself, profiting by and enjoying oneself. ${ }^{48}$ Hypomnemata were a part of training of oneself by oneself in order to gain self-control and become an ethical subject.

While Lawrence Klein does not mention Foucault in his analysis, Shaftesbury's aspirations in the field of politeness clearly open up a possibility of a Foucauldian interpretation. Thus, it seems justified to examine politeness as a technology of the self. Especially an analysis of journals as bypomnemata can prove to be quite fruitful, since practically all eighteenth-century elite women - and men - kept some

\footnotetext{
${ }^{44}$ Klein, Shaftesbury, pp. 74-8.

45 Ibid. pp. 81-5.

46 Ibid. p. 84.

47 Ibid. pp. 81-2.

${ }^{48}$ Foucault, Michel (1991), 'On the Genealogy of Ethics: An Overview of Work in Progress', in The Foucault Reader: An Introduction to Foucault's Thoughts, ed. Paul Rabinow, London: Penguin Books, pp. 363-4.
} 
kind of journal. ${ }^{49}$ It could even be said that the ethos of the polite society strongly recommended journalizing, which further enhances the validity of analyzing journals as hypomnemata. However, journals only rarely were as detailed as Shaftesbury's notebooks, or presented Shaftesbury's brand of self-scrutiny. They were often merely short memoranda of family events or places visited; sometimes they included lists of books read or recommended plays. Yet bypomnemata as Foucault describes them were not necessarily supposed to be intimate diaries, but merely aide-mémoires in which people would enter quotations, events and reflections they wanted to contemplate on later. ${ }^{50}$ Indeed, taking a look at the early journals of the novelist Fanny Burney (1752-1840), we will discover that although Burney did not use the explicit language of self-care, her journals very much served the purpose of a classic bypomnemata.

\section{Fanny Burney's Self-Fashioning}

Burney used her journals to write down her thoughts about books, people, anecdotes or events. These thoughts were intricately connected to polite society and her place in it: among other things, they touched upon women's relations to men, ideal femininity, the proper modes of entertainment and leisure, maternity and the relation between children and parents. Burney used her journals to reflect on different polite roles and to construct for herself a true polite identity. She most often presented herself in her journals as an essentially domestic, chaste and quiet young woman. In other words, she seemed inclined to assume the ideal feminine character promoted by such noted moralist conduct writers as Hannah More and James Fordyce. ${ }^{51}$ As a true Fordycean female, Burney often mused on her aversion to public amusements and preference for domestic pleasures:

To be sure I am not frequently from Home, on the contrary, I seldom quit it, considering my Age \& opportunities; but why should I, when I am so happy in it? I never can want employment, nor sigh for amusement - we have a Library which is an ever lasting resource when attack'd by the spleen - I have always a sufficiency of work to spend, if I pleased, my whole Time at it - musick is a Feast which can never grow insipid - \& in short, I have all the reason that ever mortal had to be contented with my lot and I am contented with, I am grateful for it. 52

\footnotetext{
${ }^{49}$ Cressida Heyes' analysis on Weight-Watchers' printed dieting material as bypomnemata offers an example of an study on gendered identity from a Foucauldian perspective of self-care. (Heyes, Cressida J. (2007), Self-Transformations: Foucault, Ethics, and Normalized Bodies. Oxford: Oxford University Press, pp. 81-7)

${ }^{50}$ Foucault, Genealogy of Ethics, pp. 364-5.

${ }^{51}$ E.g. More, Strictures, pp. 65, 111, 116, 201; Fordyce, Sermons, 90, 137.

52 Burney, Fanny (1988), The Early Journals and Letters of Fanny Burney, Vol. 1: 1768-1773, ed. Lars E. Troide, Oxford: Clarendon Press, pp. 60-1. See also e.g. p. 68: 'Younger sisters are almost different Beings from Elder one's, but thank god it is quite \& unaffectedly without repining or envy that I see my elder sister Gad about \& visit, \&c - when I rest at Home', or p. 146: 'I was last Night, with mama \& Miss Allen, at Ranelagh. [...] I saw few People there that I knew, \& none that I cared for.'
} 
Thus, Burney presented her ideal self in her journals as hardworking, well-read and accomplished - a true domestic treasure. ${ }^{53}$ She was especially fond of music and a decent harpsichordist, but she acknowledged the conflict between the shy, domestic feminine ideal and the competing polite ideal of an outgoing socialite, accustomed to attention. Because of her shyness, Burney was unable to perform publicly, even though she recognized the sociable need to be able to assume the role of female musical entertainer, and tried to push herself to overcome her fears:

Mr Lattice \& the Russian most furiously attacked me to play - I really recollect with pain the earnest entreaties of the latter. Yet I could not - I did not dare to comply. [...] From the moment I entertained the slightest idea of playing, my knees shook under me, so much that I could hardly support myself. [...] such extreme hipishness - I can use no better word - as mine serves only to make myself troublesome to others \& uneasy to myself - however, I take all the pains I can to overcome it. ${ }^{54}$

In other words, Burney used her journals as a means of identifying different polite roles, negotiating these roles into her own identity, observing her success at performing these roles and disciplining herself into a more thorough internalization of the proper polite identity.

On the pages of her journals Burney also negotiated other different and contradictory feminine identities. One of these roles was that of the dutiful daughter; another that of the affectionate sister. ${ }^{55}$ She generally presented herself as very reserved with men, as the morally guarded woman of the moralist conduct book should: 'Indeed, $I$ have little to fear, as I was so [maide]nly demure \& prudish \& shy, that he can not, I will be answerable, know any thing of me. ${ }^{56}$ However, she could also assume the role of a salonnière, conversing deftly with celebrated social figures on polite subjects, and in different languages. Indeed, she often recorded the praise the received for her conversation skills, as well as for her knowledge of French and Italian. ${ }^{57}$

Negotiating different feminine roles also included assessing other women's personas with a critical eye. In her journals Fanny Burney analysed the beauties of virtue and politeness as well as the effects of a vulgar address, a sullied reputation or bad personal hygiene. ${ }^{58}$ In a somewhat sarcastic passage from one of her journals, Burney assessed two women on the grounds of their appearance and behavior the former having left a favourable impression, the latter less so:

\footnotetext{
${ }^{53}$ See also e.g. Burney, Journals and Letters, Vol. 1, p. 58: 'I pass my time in Working, Reading, \& thrumming the Harpsichord.'

${ }^{54}$ Burney, Journals and Letters, Vol. 1, pp. 188-9.

55 E.g. Burney, Journals and Letters, Vol. 1, pp. 128, 243; Burney, Fanny (1990), The Early Journals and Letters of Fanny Burney, Vol. 2: 1774-1777, ed. Lars E. Troide, Oxford: Clarendon Press, pp. 123-6.

56 Burney, Journals and Letters, Vol. 1, pp. 9-10.

${ }^{57}$ E.g. Burney, Journals and Letters, Vol. 1, pp. 49, 185; Burney, Journals and Letters, Vol. 2, pp. 33, 86.

${ }^{58}$ E.g. Burney, Journals and Letters, Vol. 1, pp. 44, 276-7; Burney, Journals and Letters, Vol. 2, pp. 51-2, 55, 70.
} 
[Mrs. Seton] is rather handsome, extremely well bred, even elegant in her manners, \& mild \& sensible in her Conversation. [...] [Miss Dalrymple] is reported to be an old flame of Mr Seton's - she is about 28 or 9, rather handsome, lisps affectedly, simpers designedly, \& lookes conceitedly. She is famed for never speaking ill to any ones Face, or well behind their Backs: an amiable Character. ${ }^{59}$

Burney's musings also extended to feminine nature in general. Reading the third book of the Iliad, she feared that Homer's poor opinion of the female sex - love of beauty being its most prevailing passion - might be justified. ${ }^{60}$ Burney also transcribed many conversations - usually with men concerning the question of whether women were capable of rational self-restraint. She most often seems to have taken the positive stand - that is, she argued in her journals that women were rational creatures, capable of controlling themselves. This is evident from her description of a Miss Reid, a disorganized and dowdy figure:

[Miss Reid's] turn of mind is naturally melancholy, she is Absent, full of Care, \& has a Countenance the most haggard \& wretched I ever saw, added to which, she Dresses in a style the most strange \& Queer that can be conceived, \&, which is worst of all, is always very Dirty. The unhappiness of her mind, I have heard attributed to so great \& extraordinary an unsteadiness, not only of Conduct, but of principle, that in regard to her Worldly affairs, she is Governed by all who will Direct her, \& therefore acts with inconsistency, \& the most uncomfortable want of method; [...] Her mind is thus in a state of perpetual agitation, \& uneasiness. If she was a Woman of weak intellects, I should not wonder at her being so unfixed \& wavering; but that is by no means the Case, she has a very good Understanding. ${ }^{61}$

Thus, Burney clearly believed that women of sense were capable of self-control, and that it should be expected of them. She frowned on Miss Reid's lack of polite appearance, stable conduct and mental discipline. In short, she recognized in her a woman who had not embraced the polite feminine selfformation - unlike Burney herself, who was battling to overcome her shyness and to construct herself as a proper subject of polite society.

\section{The Self, Control and Freedom}

In The Use of Pleasure Foucault describes the care of self as a practice of freedom, and argues that controlling one's pleasures makes one free from them. ${ }^{62}$ On his view, discipline is a prerequisite for freedom. My claim is that this is also what Shaftesbury had in mind when he was formulating his idea of rational sociability: his idea was that expanding the control of the self would bring about a freedom from external stimuli and inner passions. Foucault goes on to state that this freedom is essentially a

\footnotetext{
${ }^{59}$ Burney, Journals and Letters, Vol. 1, pp. 123-4.

${ }^{60}$ Ibid. p. 37.

${ }^{61}$ Burney, Journals and Letters, Vol. 2, p. 70.

${ }^{62}$ Foucault, The Use of Pleasure, pp. 78-80.
} 
form of power: power that an individual uses over themselves, but also power that they use over others. This is why self-control was, in Foucault's analysis, a masculine virtue; it was expected from those who were in charge, and it was considered to be essential for good government. ${ }^{63} \mathrm{I}$ have claimed above that too rigorous bodily control was regarded as unfeminine: 'true' women burst occasionally into tears and blushed or fainted when appropriate. The fact that polite writers constantly presented the feminine nature as naturally prone to vanity, excess, and luxury can be seen as a way of creating passive femininity by establishing a feminine incapability of self-control. However, Fanny Burney's journals show that she not only believed women to be capable of self-control, but also that she herself was engaged in a process of self-formation, discipline and practice, in order to become an ethical polite subject. Further, the ability to burst into tears at appropriate intervals is, in fact, a very controlled sort of un-control - the kind of un-control practiced, consciously or unconsciously, by women wanting to appear soft and feminine.

If self-control was perceived as a masculine trait, the act of exercising discipline of a feminine self could be seen as an empowering act, a move away from normative passive femininity towards active masculinity. As Foucault writes, 'self-mastery was a way of being a man with respect to oneself,' whereas immoderation derives from a passivity that relates it to femininity. ${ }^{64}$ Thus, my claim is that working on oneself could bring to women the experience of power that was traditionally viewed as a masculine prerogative. In the end, however, this power would have been immobilizing as well as enabling, since the process through which it was gained - working on oneself through the discourse of politeness - aimed at isolating women from that power by producing ideal femininity - soft, uncontrolled, non-rational.

However, mastering the practices of politeness did bring women other kinds of freedom. A woman who knew the rules of propriety and politeness could bend them fairly extensively without stepping over the line and becoming impolite. In this way, women who were skilled in politeness could use it for their own ends and gain relative freedom from the restrictive idealized femininity. ${ }^{65}$ For example, many heroines of Jane Austen's novels deviate from the feminine ideal in various ways, but their knowledge of politeness still renders them respectable. Mary Crawford in Mansfield Park is a forward, masculine tomboy who boasts her strength and riding skills, while her harp-playing and demure looks still make her 'perfectly feminine. ${ }^{66}$ Ingrid H. Tague describes such persons in real life in her book Women of Quality, introducing among others Henrietta Knight, whose reputation remained

\footnotetext{
${ }^{63}$ Foucault, The Use of Pleasure, pp. 80-4. The idea of control as a source of liberty was advocated also by, for example, the political theorist Edmund Burke (1729-1797), who wrote that 'Men are qualified for civil liberty in exact proportion to their disposition to put moral chains upon their own appetites.' (Letter to a Member of the National Assembly (1791), quoted from Davidson, Hypocrisy, p. 8.)

${ }^{64}$ Foucault, The Use of Pleasure, pp. 82, 84.

${ }^{65}$ Tague, Women of Quality, pp. 184-5.

${ }^{66}$ Austen, Jane [1814] (1994), Mansfield Park, London: Penguin Books, p. 65.
} 
intact through a scandalous love affair and a public separation from her husband, and Henrietta Howard, who used her knowledge of politeness to participate actively in Whig politics, a public arena not usually available to women. ${ }^{67}$ Tague also points out that women used the rhetoric of politeness in a creative way: as a means of making their ambitions appear legitimate and achieving their aims, such as social power. ${ }^{68}$ Like Fanny Burney's journals also demonstrate, women could assume different kinds of subject positions within the polite sphere - that of a dutiful mother, patriotic wife, fashionable lady of town and so forth - and also swap them according to different situations in order to facilitate their navigating in the polite social world.

On a wider scale, Cressida Heyes, in her analysis of modern dieting, has pointed out that self-care also provided a certain kind of satisfaction for the dieter. ${ }^{69}$ The same applies to politeness: caring for one's body, dressing it, and exercising it would have provided the same kind of pleasure and fostered the same kind of attentiveness towards the self as Heyes observes dieting to do. ${ }^{70}$ In addition, learning to master such skills as dancing a graceful minuet would have brought about a feeling of mastery and achievement. That achievement also had concrete results in the form of securing and elevating one's status within polite society, which in turn could result in better marriage proposals either wealth- or connection-wise. Thus, mastering polite practices gave women power over their own lives; , at least to some extent, it was a means of taking control of their own future.

Cressida Heyes claims that discursive normalization has at a simultaneously homogenizing and individualizing impact on the population. The care of the self, while aimed at producing normativity, is experienced by individuals as improving their self-knowledge and even as revealing their "true self." This is also what Shaftesbury, and to some extent Fanny Burney, were aiming at. Foucault calls this process 'the ontological recognition of the self by the self', which is a prerequisite for achieving discipline and virtue. ${ }^{72}$ What needs to be noticed, however, is that this self-discovery has nothing to do with ontological selfhood, simply because there is no such thing. What Foucault means by ontology of the self, or the relation of the self to the truth, is a self-discovery within an episteme of truth - or in other words, self-fashioning according to a discursive form of knowledge. ${ }^{73}$ There is, thefore, no discovery of a non-discursive self but, as Foucault points out, the feeling of self-discovery is necessary if the individual is to able to assume ethical and aesthetic subjectivity. In this way, working on the body turns into making oneself into oneself - and politeness becomes not only a means of producing docile bodies but a practice of individuality. Of course, these individual identities were not individual in the

\footnotetext{
${ }^{67}$ Tague, Women of Quality, pp. 175-88.

68 Ibid. p. 214.

${ }^{69}$ Heyes, Self-Transformations, pp. 67, 77-8.

70 Ibid. pp. 80-1.

${ }^{71}$ Ibid. pp. 36, 97-100.

${ }^{72}$ Foucault, The Use of Pleasure, p. 88.

73 Ibid. p. 89.
} 
sense that they would have been in some way separate from polite discourse or the result of a free choice. The imagined possibility of individuality can be seen as a subtle technique of internalizing the polite truth regime on an individual level.

\section{Epilogue}

In this paper I have taken a somewhat novel approach to eighteenth-century politeness - namely, Foucault's theory of power/knowledge and the construction of subjectivity. My claim has been that the disciplinary system that Foucault describes in Discipline and Punish can be seen at work within eighteencentury discourses of politeness, making this set of social practices a panopticon of surveillance and self-improvement. At the same time, Foucault's later works, especially The Use of Pleasure, shed light on the other side of polite life, and enable an analysis of politeness as a practice of working on the self. The journals of the Earl of Shaftesbury and Fanny Burney demonstrate the process of self-evaluation and practice required in adopting and internalizing polite identities. The concept of control is central to both of these Foucauldian frameworks, working firstly as a panoptic, constant surveillance of others and self, and secondly as a more positive requirement of self-care and subjectivity ultimately needed in achieving individuality. Based on this analysis, I argue that Foucault's theories of power in many ways provide a fruitful method for analyzing the polite discourse of eighteenth-century England.

I would like to end with a few words on resistance, the logical next step for many feminist scholars seeking to adopt a Foucauldian analysis of power structures. In a polite panopticon where even individualizing practices turn out to be tactics of truth internalization, was there a possibility of resistance? Foucault himself seems to be hopeful, famously writing that 'where there is power, there is resistance', but leaves disconcertingly vague what concrete forms such resistance could take on. ${ }^{74}$ Johanna Oksala has analysed Foucault's views on resistance; her conclusion is that the experiential body offers a means of resistance when it crosses over discursive borders. ${ }^{75}$ According to Oksala, this should not be taken as referring, as Judith Butler has suggested, to a pre-discursive body, but as suggesting that since truth regimes or epistemes are by nature exclusive and contradictory, there is an outside of them and that is the area of resistance. ${ }^{76}$ Applied to the eighteenth-century polite episteme, what would this mean? Would radical bodily transgressions of gender boundaries have qualified as acts of resistance? Perhaps, for example, the famous case of Chevalier D'Eon's public cross-dressing and doubtful gender, or Hannah Snell's equally well-known masculine warrior impersonation could be seen as constituting

\footnotetext{
${ }^{74}$ Foucault, Michel (1998), The History of Sexuality: The Will to Knowledge. Transl. Robert Hurley, London: Penguin Books, p. 95.

${ }^{75}$ Oksala, Foucault On Freedom, pp. 124-34.

${ }^{76}$ Oksala, Foucault On Freedom, pp. 125-8; Butler, Gender Trouble.
} 
resistance. ${ }^{77}$ On a smaller scale, perhaps everyday acts of feminine empowerment, such as using polite ideals consciously to gain power, could be interpreted as forms of resistance. But perhaps only an act of complete incomprehensibility would count. For if resistance needs to come from an area outside the limits of an episteme, does that not rule out everything but acts that would have been defined as lunacy?

\footnotetext{
77 These cases of obscure gender are introduced by e.g. Dror Wahrman (2007) in The Making of the Modern Self: Identity and
} Culture in Eighteenth-Century England, New Haven: Yale University Press, pp. 29-35. 